DOI: https://doi.org/10.24297/jssr.v15i.8634

\title{
Discriminatory Practices in School Environment and Their Elimination Through School Mediation in Slovakia
}

\author{
Katarína Vanková \\ University of Constantine Philosopher Faculty of Social Sciences and Health Care Institute of Romological \\ Studies
}

kvankova@ukf.sk

\section{Annotation:}

Teaching about human rights and freedoms means teaching about human dignity, tolerance between people, acceptance of people as they are, justice, equality, self-control, and self-assertiveness. Not to allow unfairness, deception, injustice, inequality, the humiliation of oneself and others. Tolerance in the school environment includes the acceptance of different views, different behaviors, a different relationship, but also toleration and patience in relation to others. A pupil who is unable to cope with conflicts is unable to adapt to changes and risks his own decline. The main problem is not that there are conflicts between us, but in the way how we respond to them, how we can deal with them, and what we do to prevent them, or what we do to successfully resolve them. Conflicts in the school environment are a natural part of school life, indicating, in particular, the presence of differences. Conflict resolution through school mediation represents the ability to not only perceive, understand but particularly respond to and resolve conflict situations with the help of a third neutral person. School and peer mediation can be a way how to teach pupils to develop strong friendships, even in an environment of diversity and differences; it can be a preparation for inclusive educational system.

Keywords: Pupils. Difference. Problem. Otherness. Conflict. School Mediation.

It is most effective and important to start by education towards respect and tolerance, already in pre-primary education, because the primary objective of pre-primary education is to achieve an optimal perceptive-motor, cognitive and emotionally-social level as a basis of preparation for school education and life in society. A foundation is the child's uniqueness, active learning, and inclusion in a group. The child socialises more easily and is able to accept otherness. Pre-primary education helps children:

- Strengthen respect for their parents, and the cultural and national values,

- To their mother tongue, an official language, and their own culture,

- Gain and strengthen respect for human rights and fundamental freedoms,

- Prepare themselves for life in free society in the spirit of understanding and tolerability,

- Tolerance, gender equality and friendship between peoples, national and ethnic groups, and churches and religious communities,

- Learn to develop and cultivate their personalities, prepare for further education,

- Learn to cooperate in a group, and take adequate responsibility,

- Learn to protect their health, including the use of healthy diet, and to protect the environment,

- Learn to respect the panhuman ethical values.

Education needs to be deepened practically all life from pre-primary, primary, secondary, tertiary education and to complement knowledge in the context of further lifelong learning. (Rác, I., 2012, Kozubík, M. - Kajanová, A. Kozlová, L., 2018) Because education, vocational training, and lifelong learning play a particularly important role in economic and social strategies at both national and transnational levels. (Lužica, R. - Segretain Arnaud, 2018)

In pupils, education in the spirit of multiculturalism encourages the knowledge, development, incitement particularly in the following ways: 
- To develop the awareness of one's own identity, pleasant experiencing of one's own cultural and ethnic heritage, and even the feelings of pride in it. However, this awareness cannot be confused with one's own cultural and ethnic superiority. It relates to all participants, both a dominant group and minorities.

- To explore other cultural and ethnic groups. It is not possible to perceive them and respond to them sensitively without knowing anything about them. The accuracy of information is extremely important.

- To provide specific examples of similarities between people. Revelation of multiple similarities, which really exist, forms the basis for overcoming anxiety.

- To encourage understanding of differences such as racial, cultural, ethnic, and religious. An ability to learn from them and not only tolerate them. To understand that if someone is different, it does not mean he is better or worse - he is only different.

- To identify obstacles to mutual understanding, barriers to mutual contact, such as stereotypes and prejudices.

- To develop an ability to improve communication between ethnic groups, for example, by the ability of active listening; to avoid "labelling" others, understanding for non-verbal behaviour, etc.

- To create the consciousness of the world as one human family, where people struggle and work on a common cause. In this case, people's lives could be richer during the development of such consciousness.

In this century, interpersonal education and multicultural education are as important prerequisites for successful societal development as scientific or technical achievements of this period. By this process, the attitudes and skills related to differences in many aspects are acquired. It means that it is more than necessary to develop understanding, tolerance, acceptance, empathy into otherness, differences, and to realize one's own stereotypes and prejudices, and such attitudes result in prevention and also elimination of problems, conflicts and misunderstandings (Vanková, K., 2014, Minarovičová, K., 2013, Rosinský, R. - Samko, M., 2015).

In the present, the environment in today's schools is affected by great diversity. (Lehoczká, L., 2010) On the one hand, the quality of those who invested time also in improving interpersonal relationships is increasing, but in the same degree, we see an increase in conflict situations where the natural authority of the school leader and teachers is replaced by power games. In the environment where positive interpersonal relationships should be developed in the protective barriers of adult guidelines, children become witnesses of avoidance of problems or their inappropriate resolution from the position of power. If we realize that the community of peers is at a certain age for children the most natural environment of sharing their authentic feelings, thus the role of the teacher in the level of conflict resolution needs to be changed in its character. Pupils need to learn to be responsible for their actions. In order to feel their responsibility, they must also be involved in its development; they must know that their word is heard, their opinion is taken seriously, and a conflict is only an opportunity to learn how to understand the world of others. (Rosinský, R., 2011, Rusnáková, J. - Rochovská, A., 2016, Čerešník, M. - Čerešníková, M., 2018)

School and peer mediation can be a way to teach pupils how to develop strong friendships, even in an environment of diversity, otherness, and differences. It can also be a good preparation for inclusive educational system.

In the developed countries where a life philosophy of schools is to solve school conflicts through mediation, which has become prevention against discriminatory practices and bullying, pupils have become more receptive to otherness, and they tolerate and accept the differences in their classmates more. (Lauren B. Edelman, 2003)

Mediation is particularly appropriate for the field of education, as there are often "delicate issues" in which the participants often prefer discretion, and also effective and rapid settlement of disputes. A variety of problems and conflicts can be tackled at school:

1 School mediation - it resolves conflicts between pupils, teachers, pupils and teachers, parents and teachers, and between teachers and management. In such mediation, the participation and management of the entire mediation process by a professional mediator are convenient. 
2 Peer mediation - it is suitable as a service for pupils, students (of elementary, secondary schools), which helps pupils deal with disputes at school, but also learn the negotiation, communication skills. It is also a preventive method for resolving small disputes that have not become more serious yet, and thus the overall positive climate and culture of school increases.

Conflicts between pupils are mostly resolved through peer mediation, which has two basic principles:

- Peer principle - after a training, pupils are able to help resolve a conflict between classmates even without the teacher's intervention.

- Principle of mediation - when dealing with a conflict, a third person (pupil, teacher) assists the interested parties.

Peer mediation means resolving a conflict, a misunderstanding between peers in the school environment conducted by peer mediators. We know it also as "school mediation" or "peer mediation." It emphasises that the concept of "school mediation" is broader than "peer mediation." Unlike school mediation, which helps resolve conflicts between pupils, teachers, pupils and teachers, parents and teachers, and school managers and community representatives, peer mediation (usually at primary and secondary schools) helps deal with conflicts between peers. Peer mediation contributes to the development of psychosocial competences and prosocial behaviour in children. School mediation, in particular, focuses on creating a favourable atmosphere in which there is an opportunity to look for solutions by both parties. However, it should be emphasised that a conflict as such is not anything unusual, particularly in the school environment and certainly is part of the spectrum of interpersonal communication. Of course, we do not mean that we should seek conflicts; however, it is necessary to accept the fact that sometimes each of us gets into a certain dispute. Then we can focus on their meaningful resolution. School, peer mediation, is, according to Vanková (2018), characterised as mediation in which a third party is a peer, a student who helps his classmates deal with their own problem from the position of the third neutral party. The peer mediator facilitates and creates a problem-solving process by encouraging the students to negotiate their interests in a fair way and to make a mutual agreement on how to resolve their problem. A mediator may also be a teacher or other school employee who has mediation skills and can use them for unauthoritative resolution of conflicts between students.

Counselling in the education system is represented by a system of educational counselling and prevention in which particularly psychological, pedagogical, special pedagogical and social activities are carried out to optimise the educational, mental, social, and career development of pupils.

According to Bieleszová: "Pupils do not have sufficient skills that would be an adequate response to alleviate stress in the school environment. Classmates sometimes try to ignore incidents between peers, sometimes in order to protect a friend, they use an aggressive counter-attack. The brutality of the attacks increases. Tolerating the vulgarisms in the school environment can outgrow into a malicious habit of perceiving them as a regular manifestation. This condition can shift the boundaries of perceptions of what is polite and impolite. Conflict resolution through negative models is more and more confirmed in children. They use the mechanisms to interpret external phenomena as natural part of the evolution of time" (Bieleszová, D., 2012, p. 3; translated by the study author).

Most often, school mediation is used in various types of problems, such as defamation, verbal quarrels, harassment, classroom behaviour, jealousy, beating or anticipated beating, invasion of privacy, and intergroup conflicts. Thus, the focus of mediation in the school environment includes:

- Conflicts between: teachers; teachers and school managers; parents and school; and school and municipality. These conflicts are resolved by professional, or trained voluntary mediators.

- Conflicts between pupils and teachers, and between pupils, which most commonly is violation of the school rules and principles of good behaviour; generally, they are resolved through so-called peer mediation. 
The Peer Mediation Training Programme is attended by teachers and the selected number of pupils who are then active as mediators, and the whole school is informed about the possibility of resolving their conflicts through mediation. Mostly, the disputants are referred to mediation by teachers or another classmate, or they decide for mediation on their own; they make an appointment with a mediator in person or through a mediation mailbox that is placed in the school premises (Vanková, 2013).

The idea of peer conflict resolution comes from the USA, where the first educational projects against violence responding to the growing ethnic and social tensions occurred in the $60 \mathrm{~s}$ and $70 \mathrm{~s}$. In the $80 \mathrm{~s}$, there were several active organisations and centres in the USA, which supported school conflict resolution programs for pupils and teachers. Alternative conflict resolution became part of education, and later - including mediation - it was integrated into official school schedules (Vanková, K., 2018).

In the USA, there are about five thousand secondary and primary schools where peer mediation works well, and the success rate in resolving conflicts is 50 to 80 percent. Similar programmes have also been used in Canada, Australia, Israel, Ireland, Holland and Germany. The first attempts to introduce peer mediation in schools have also occurred in Poland and Hungary. The research has shown that the atmosphere in schools clearly improved after the introduction of peer mediation, the number of conflicts solved by aggression declined, and teachers did not have to deal and cope with disputes between pupils so often.

An undisputed benefit of peer mediation is the fact that young people (pupils, students) learn to deal with their own conflicts, which will help them overcome perhaps much greater and more challenging obstacles in the future (Vanková, 2018).

\section{School mediation helps resolve the following groups of conflicts most often:}

- Defamation - a dispute of a type she said - he said, talking behind one's back - individual statements are perceived by one of the parties as inadequate, offensive, false, taunting and deflating, etc.

- Verbal quarrels - verbal exchange of opinions between individuals or groups - misunderstandings, personality and individual differences, disagreement, shouting, being fed up...

- Harassment - verbal and nonverbal behaviour that the other party perceives as annoying, threatening, sexually unpleasant or provocative - from looking to gestures, verbal harassment - mocking, swearing to physical, sexual harassment, and bullying.

- Behaviour in the classroom - disturbing other classmates during the lessons so that they cannot focus on the educational process - harassing copying, joking, speaking, nudging, clowning, etc...

- Jealousy - among classmates (friends), of classmates, friends, jealousy of achievements at school or in afterschool activities, jealousy of a partner relationship of a classmate because they date another person, etc...

- Beating or anticipated beating - use of physical force or threatening behaviour.

- Invasion of privacy - stealing private items, borrowing and using them without permission, disclosure of confidential information about a classmate, friend, another person, etc...

- Boys dating girls - disputes about who is dating who and why, and why they split, who started to date whose girlfriend, boyfriend - jealousy in co-called school partners.

- Conflicts between groups - conflicts of opinion, racial or minority conflicts, verbal and physical attacks between individual antagonistic (opposing, hostile) groups - metalheads, skinheads, punk rockers, junkies, etc... 
- Territorial disputes - disputes relating to possessing a territory - in the school, usurping a particular place by a group; usurping a seat; during a trip, the quarrels about beds in a cottage, who's going to sit where at the beginning of a school year or in the cinema, and who usurps too much space on the desk, etc...

- $\quad$ Class or group decision making - where to go on a trip; how to spend money saved for the Prom Night; when, where and under what conditions to make a celebration; who will represent the class in a school or afterschool events... (Civilná mediácia, 2011, Vanková, 2018)

The factors that can affect conflicts in the school environment include: character traits of the disputed parties; different value systems; duration of friendship; generation gap; rosy retrospection of the past times; different social environments; persistent stress; long-term frustration; highest qualification; status; strong ambitions; sense of precision; reliance on intuition; presence of onlookers in the dispute, their insensitive inclusion in the subject (Bieleszová, 2012, Vanková, 2018).

In the developed countries, this form of conflict resolution becomes a prevention and a life philosophy of schools. Children learn how to solve their own conflicts without violence and humbly using the specific examples and models of real situations. They find out that success in life does not lie in ruthlessness, aggression, dominance, but in understanding of the experiencing of another person through getting familiar with his opinion and attitude. Of course, all forms and techniques must be tailored and must correspond to the understanding and age of children.

Unfortunately, mediation does not have a long tradition in our schools yet. The child is often put into a position of a predator that must be successful and meet the goals regardless of others. It is often child's own parents who meet their desires through their children's value system. Later, it is manifested by bullying the classmates, in aggressive and ruthless behaviour against teachers. The reasoning that "my child is nobody's fool", "times are difficult", or "only the best can win" are unfortunately a reality. Peer mediation, and thus the pupils, who either voluntarily or by recommendation from their classmates and teachers want to participate in such a programme, can help resolve conflicts. Unlike the empty sections, warnings or prohibitions, it enhances the behaviour and communication of our children to the level of decency, fairness, morality, quality interpersonal relationships, and mutual respect, which pupils, students, and then parents bring into everyday life.

We could say: the more people will have the skills in conflict resolution, the more likely the conflicts will be tackled more efficiently and without unnecessary relationship harm, even if there are going to be as many conflicts as today.

\section{Areas in which conflicts in the school environment are most likely to occur:}

Discriminatory practices in the school environment. A discriminated person can be anyone who is treated less favourably than another person in a comparable situation during exercising the rights and obligations. As mentioned above, a natural person may be discriminated. Thus, each of us may be discriminated on grounds which are defined by the Anti-Discrimination Act. These reasons are in particular: sex, gender, religion or belief, race, nationality or ethnic group, disability, age, sexual orientation, marital status, and family status, skin color, language, political or other opinions, national or social origin, property, gender, or another status.

The attitudes of tolerance and intolerance in today's youth and their discriminatory attitudes and behaviour in relation to persons, groups of persons who are different, in our case, it is the second-largest national minority Roma - that has direct and indirect experiences with discrimination. Due to the escalating conflicts between the majority and minority groups of pupils, it is necessary to eliminate these escalated conflicts and disputes by peer mediation already at a young age (Vanková, 2018). We can say that peer mediation is a peer resolution to conflicts, disputes, escalated problems through mediation in schools and school facilities. It is built on two basic principles: 
- Peer principle - after a training, pupils are able to help resolve a conflict between classmates even without the teacher's intervention.

- Principle of mediation - when dealing with a conflict, a third disinterested person (pupil, teacher) assists the interested parties (Vanková, K., 2013).

The Peer Mediation Training Programme is attended by teachers and the selected number of pupils who are then active as mediators, and the whole school is informed about the possibility of resolving their conflicts, disputes, escalated problems through mediation. Mostly, the disputants are referred to mediation by teachers or another classmate, or they decide for mediation on their own; they make an appointment with a mediator in person or through a mediation mailbox that is placed in the school premises.

There may also be discrimination in access to education. A typical example of such discrimination is the unlawful inclusion of a child in a special school or class. Roma children are sometimes unreasonably included in special schools. After finishing a special school, it is naturally more difficult for children to study further or look for a job. Children who finish a special school cannot study at a standard secondary school. They will never be able to pass a school-leaving examination or continue, let's say, in education at university. Other possible reasons for discriminatory action in the area of education are:

- Special classes or schools for Roma children (segregation),

- Worse conditions for education for Roma children.

A typical example of when a Roma child has worse conditions in access to education, for example, is lending school textbooks. Such a textbook is lent to a "white child" without any problems but not to a Roma child because they fear the textbook will be destroyed. Other discriminatory manifestations in education may be:

- Unjustified rejection of the child's admission to kindergarten,

- Unjustified rejection of the child's admission to primary school,

- Poor behaviour of teachers towards Roma children; hostile environment in schools directed against Roma children, smaller demands for Roma children in education, etc. (Ivanco, 2010).

The word bullying comes from the French "chicane", which means repeated deliberate harassment, persecution, abuse, manipulation, humiliation of someone who cannot or is not able to defend themselves. The main feature of bullying is the imbalance of power/strength; it includes all forms of psychological and physical violence against a victim committed by an individual or group. Bullying is such behaviour when one or more pupils deliberately and repeatedly harm a selected pupil, do (say) something that is unpleasant for him (Bizíková, 2007).

Bullying in the school environment is a psychological, pedagogical, and legal phenomenon. Furthermore, we consider it a problem that the current school needs to define and address immediately.

The concept of bullying in the school environment can be analysed from the following three aspects:

- Psychological as specific behavioural disorders,

- Pedagogical as a problem behaviour;

- Legal as a violent crime committed by a child or a juvenile; in case of a bullying juvenile, we may speak of juvenile delinquency.

The three aspects of the assessment are mutually interlinked and supplemented, as the issue is comprehensive, and it is almost impossible to get school bullying as a problem behaviour from its psychological context of a behavioural disorder, nor to omit its legal impact (Biknerová, 2010). 
The role of school prevention is to work out a code of school discipline and a system of educational measures, in the school's internal order to anchor clear rules on prevention of bullying, harassment, violence, vandalism, and other forms of pathological phenomena. It is difficult to promise the pupils the $100 \%$ protection, but teachers can advise a victim to avoid dangerous places, they should have an aggressor in the school under constant supervision, as well as to arrange in school such a place for the victim where he can go if he feels to be threatened and frightened. It is advisable to choose specific teachers or pupils whom the victim can contact, and to convince the child to report when the attacker attempts to bully again. If we are not informed, we cannot help.

A significantly lower incidence of bullying is found where bullying prevention is given due attention, where clear rules are valid, and the compliance with them is consistent, where good interpersonal relationships and open communication are used. On the other hand, bullying is encouraged by inconsistent application of the rules, feelings of injustice, as well as favouring of pupils (Biknerová, 2010, Vanková, 2013, 2018).

Furthermore, we must mention problem students in this group. In the present, highly developed society puts more and more emphasis on general education and special training for work activity. In this context, the demands that the school puts on children are increasing. Therefore, the increasing number of children is at risk of failures that result from their inability to meet all the requirements made by both school and family. The child who is not successful in school is referred to as "dull" or "sloppy". The pressure on the child increases, which closes a vicious circle from which neither the child, nor his parents or teachers find a way out. Then, a group of so-called problematic pupils occurs. The aid should be sought in the detection of all the causes that lead to problems in school, particularly in knowing all individual shortcomings and the compensatory possibilities of the child, and in the thorough knowledge of the child's whole social background (Polcková, 2007).

The advantage of resolving conflicts through mediation at school is the voluntary nature of disputants when entering mediation. At the same time, the chances are that we will not have to deal with the same problem in the future. Thus, in the school environment, by allowing peer mediation, we will provide pupils and students with a new social experience and a mediation skill that will strengthen their autonomy.

The objective of peer mediation is to reduce the number of conflicts at school resolved by aggression so that the conflicts are resolved among pupils without the necessity of teachers' interventions. Furthermore, it is a conviction that if pupils and students take responsibility for dealing with their disputes, conflicts, they will acquire the skills and abilities that will direct them towards effective conflict resolution; it will help them strengthen interpersonal relationships; and they will learn to think critically, which is not offered by schools today.

However, the practice is such that the introduction and mediation of such programmes to schools is not as effective, fast, and planar as would be required in the present time. If the school has creative educators and the management supports them, it is possible to introduce peer mediation in their school. At the beginning, it is advisable to contact a professional mediator who can help start the process of school mediation.

\section{School Parliament}

Before the introduction of peer mediation at school, it is advisable to create a school parliament composed of two elected pupils from each class.

The representatives of their classmates express their views and interests in the Parliament, submit proposals for new school activities, and seek solutions to current problems.

The Parliament's efforts should be to achieve the cooperation between teachers and pupils in developing and implementing joint action plans; to replace the passive participation of pupils in social events by their direct activity in the selection, preparation, implementation, and evaluation of various events: to teach pupils to speak publicly, to properly argue their views and the views of their peers from classes, to have a certain degree of responsibility for life in their school, and to promote self-confidence, autonomy, creativity and to enable the 
self-realization of pupils; and to experience a school of democracy and life in a small extent. It is advisable to eliminate the teacher - pupil barriers, which contributes to their autonomous thinking and action. It is also advisable to eliminate and prevent mutual misunderstandings.

\section{Mediation box}

In pedagogical practice, it has shown to be practical to use a wooden box in a visible place in the lobby of the school for the purposes of mediation. The box should be locked, and the keys from it should be kept by a teacher - a coordinator who is responsible for running the School Parliament at school. Pupils can use the box to submit their proposals, and also various complaints related both to their classmates and teachers.

Also, according to the studies (Ondrušek - Shapiro, 1999), the agreements were reached in about $70-80 \%$ of cases; in the monitored problem students, their aggressive manifestations decreased by $47 \%$; and in many studied schools, the problems linked with aggression in children decreased by more than $50 \%$, in general. More than $60 \%$ of teachers who completed conflict resolution programmes, in the research confirm that they use the gained skills to effectively manage the class and maintain discipline. In addition, they improved their work methods and methods of managing the class in communicating in a non-threatening way, active listening, and in tackling problems with their pupils (Havráneková, 2011).

The Ministry of Education, Science, Research and Sport of the Slovak Republic in the Pedagogical and Organisational Instructions for the School Year 2018/2019 in the part on prevention in the education process also recommends mediation to schools:

- Implement peer mediation programmes focused on resolving conflicts between pupils in the form of the agreement, alleviation of tensions in classes, and working with group dynamics.

\section{To the founders and directors, it recommends:}

- Try to settle the dispute out of court before the legal proceedings and use mediation in accordance with the Act No 420/2004 Coll. as amended;

- In fulfilling the section 55 of the Act No 317/2009 Coll. on pedagogical and professional staff and the amendment of certain acts (hereinafter "Act No 317/2009 Coll.") during education on conflict resolution also to use the training in the area of school mediation as an effective conflict resolution method with the use of agreement.

\section{Conclusions:}

School mediation teaches tolerance. Mediation brings pupils to the ability to perceive things from different points of view. The clarification of attitudes is a matter of patient explanations, supplementation of ideas, reasoning, argumentation, reformulation of statements that result from negative emotions. It cultivates a skill to allow time for decisions. By sharing the feelings that raised a particular attitude, it brings the element of respect into communication, and helps understand the differences between people. If dealing with the agreements is in the hands of peers, pupils are more willing to take responsibility for their fulfilment, the pupil enters the mediation process with confidence, thereby increasing the chances of greater openness in speeches. Mediation allows pupils to understand their own emotions in contact with the emotions of others; it teaches them appropriate reactions that take into account the stage of the conflict and its intensity; it leads to the processing of emotions, to critical thinking, to asking questions, and to active listening; and it teaches autonomy. Thanks to mediation, children have a greater need to share common topics and also discuss those that could seem to divide them. Peer mediation improves the atmosphere at school. Anchoring the ability to solve problems through mediation is not a matter of chance but of patient explanation. Its results will appear in the form of fewer conflicting situations that would have to be addressed by the teacher. It is not possible to implement teaching at a time when the focus of the pupils is dispersed, and the teacher must pay attention to 
resolving conflicts in the class. If pupils acquire the skills of peer mediation, they will be able to resolve simple conflicts without teacher's interventions. Furthermore, mediation improves relationships between adults. Class teachers tend to be sensitive to criticism of their classes. Often they have the need to defend "their" pupils, which results in disputes between colleagues. Mediation helps perceive conflicts as a natural part of life.

Today's school teaches pupils to write, count, understand history, chemistry, physics, biology, and how the world and society work. However, it does not teach social or communication skills, which would help in coping with problems and emerging conflicts.

How we behave in a conflicting situation is very important, because based on our behaviour, others form an opinion about us. Therefore, at schools, it is highly beneficial to introduce alternative forms of conflict resolution - school mediation, which brings many positives. Not only do pupils and students take responsibility for their conflicts, but they also learn the skills and effective communication and understanding of the counterparty. They learn another way of thinking, and ultimately also the development of relationships in the future. The mediation process itself also gives us an educational message - reinforcing autonomy, confidence in the parties in a nonaggressive conflict resolution. By his personality and behaviour, every teacher significantly influences the events at school, and therefore he should be an example of positive behaviour towards others. But not everyone has such skills, they are not natural but are acquired through learning, so it is necessary and appropriate to complement education in social and communication skills and trainings, which would be helpful to their nonaggressive management not only in the school environment. To be able to transfer knowledge to their pupils and students, primarily the teachers themselves must have it. Therefore, it is necessary to supplement training opportunities for professional growth and learning, which have existed only randomly and in a very small extent so far.

We should never allow conflicts to rule our lives. It is us who must be able to rule our problems and conflicts!

\section{References:}

1. BIELESZOVÁ, D.: School mediation in school environment. [online].2012, [cit. 30-11-2017]. Dostupné na internete: <http://www.uspesnaskola.sk/skolska-mediacia-v-prostredi-skoly/>

2. BIELESZOVÁ, D. 2017. School and peer mediation. Conflict resolution in schools and school facilities. Wolters Kluwer, 2017. 41 s. ISBN 978-80-8168- 735-8.

3. BIRKNEROVÁ, Z. 2010. Eliminating aggression and bullying through prosocialism. Prešov: Prešovská univerzita. [online]. 2010. [cit. 2017-11-19.] Dostupné na internete: <http://www.prohuman.sk/pedagogika/eliminacia-agresivity-a-sikanovania-prostrednictvomprosocialnosti>.

4. BEDNAŘÍK, A. 2001. Conflict solving. Handbook for educators and youth workers. Centrum prevencie a riešenia konfliktov. Partners for Democratic Change Slovakia. Bratislava. 2000. ISBN 80-968095-4-7.

5. CIVIL MEDIA [online]. 2017,[cit. 30-11-2017]. Dostupné na internet: < http://www.mediatornovezamky.sk/rovesnicka_mediacia.html >

6. ČEREŠNÍK, M. - ČEREŠNÍKOVÁ, M. 2018. School self-concept of children in the system of lower secondary education in Slovakia -comparison of Slovak and Roma children. DOI 10.18421/TEM71-26. In: TEM Journal. - ISSN 2217-8309, Roč. 7, č. 1 (2018), s. 211-218.

7. IVANCO,Š. 2010. Say no to discrimination. Košice: Hi- Reklama. Poradňa pre občianské a ludské práva. 2010. 44 s. ISBN 978-80-970354-6-4. 
8. HAVRANEKOVÁ, I. 2011. Mediation in the school environment. [online]. Dostupné na internete: http://www.najpravo.sk/clanky/mediacia-v-skolskom-prostredi.html

9. KOZUBÍK, M. - KAJANOVÁ, A. - KOZLOVA, L. 2018. Ethnic approach in social work with social excluded groups and critical social work alternatives. In: Socialni prace/Sociálna práca : časopis pro teorii, praxi a vzdělávaní v sociální práci / časopis pre teóriu, prax a vzdelávanie v sociálnej práci. - ISSN 1213-6204, Roč. 18, č. 3 (2018), s. 70-83.

10. LAUREN B. EDELMAN. 2003. Legal ambiguity and Symbolic Structures: Organizational Mediation of Civil Rights Law. American journal of sociology, Volume 97, Issue 6, (May 1992), 15311576.StableURL:http://links.jstor.org/sici=00029602\%28199205\%2997\%3A6\%3C1531\%3ALAASSO\%E2 $.0 . \mathrm{CO} \% 3 \mathrm{~B} 2-5$

11. LEHOCZKÁ, L. 2010. Multicultural education: current reflections on multiculturalism and its role in the educational process. In: Vychovávatel'. - ISSN 0139-6919, Roč. 58, č. 5 (2010), s. 2-7.

12. LUŽICA R. - SEGRETAIN, A., 2018. The education of Roma students in Slovakia: between segregation, assimilation, integra,tion and inclusion. In: Revue internationale d éducation. - Paris : Centre international d'études pédagogiques, 2018. - ISSN 1254-4590, Vol. 78 (2018), p. 91-103.

13. MINAROVIČOVÁ, K. 2013. Strengthtening parenting competencies the role of social worker in the process of remediation of families.In: Clinic social work journal. - ISSN 0091-1674, Vol. 4, no. 2 (2013), p. 116-118.

14. ONDRUŠEK - SHAPIRO, 1999. Mediation in the school environment. [online]. Dostupné na internete: http://www.najpravo.sk/clanky/mediacia-v-skolskom-prostredi.html?print=1

15. Educational and organizational instructions for the school year 2018/2019, 2018. Ministerstvo, školstveryvedy, výskumu a športu Slovenskej republiky, s. 25 a 56.

16. POLCKOVÁ,V. 2007. Troubled pupils. [online]. 2010. [cit. 2017-11-19.] Dostupné na internete: <http://polckova.szm.com/vyvinovePoruchyuceniaaspravania.htm>.

17. RÁC, I. 2012. Movement $R$ - civic association of teachers and educators of Roma students. In: Roma in Visegrad countries: history, cutlure, social integration, social, work and education. - Wroclaw : PROM, 2012. - ISBN 978-83-62969-13-5, S. 303-310.

18. ROSINSKÝ, R. 2011. Analysis of teaching multicultural education in primary schools and sustainable development of society.In: Udržitelný rozvoj v podmínkách ekonomické krize : STUDIA 1/2011. - České Budějovice : Vysoká škola evropských a regionálních studií, 2011. - ISBN 978-80-87472-02-0, S. 384-392.

19. ROSINSKÝ,R. - SAMKO, M. 2015. Research study on language competence in roma pupils in first year of school attendance in Slovak republic. In: ICERI 2015 : Proceedings from 8th International Conference of Education, Research and Innovation, Sevilla, 16-18 November 2015. - Sevilla : IATED Academy, 2015. - ISBN 978-84608-2657-6. - ISSN 2340-1095, CD-ROM, p. 3677-3682.

20. RUSNÁKOVÁ, J. - ROCHOVSKÁ, A. 2016. Social exclusion, segrega,tion and livelihood strategies of the Roma communities in terms of asset theory. In: Geograficky Casopis. - ISSN 0016-7193, Vol. 68, no. 3 (2016), p. 245-260. IF=neuvedený IFM=neuvedený SNIP=0,505 Q WoS=neuvedený Q Scopus=Q2

21. VANKOVÁ, K.: Study of Civil Dispute Resolutions by Social Mediation Services in Civil Law, 2016. DOI 10.15405/epsbs.2016.05.9. In. 4th icCSBs : Proceedings Book from Annual International Conference on Cognitive-Social, and Behavioural Sciences, Kyrenia, Cyprus,10-12 May 2016. - Nicosia : Future Academy, 2016. - ISSN 2357-1330, online, p. 76-89. 
22. VANKOVÁ, K.: Social justice.Nitra: UKF FSVaZ,2013, ISBN 978-80-558-0270-1.

23. VANKOVÁ, K.: Probation and Mediation Service. Fakulta sociálnych vied a zdravotníctva UKF, Nitra. 2015. ISBN 978-80558-0748-5

24. VANKOVÁ, K.: Mediation in civil law in the service of man. OZ "SPONKA" Nitra. Garmond. Nitra. 2018. ISBN 978-80-570-0227-7

25. VANKOVÁ, K.: Training mediators in civil law on discrimination and equal treatment; recenzent: Jána Gabura, Michal Oláh, 2017. In. Súčasné trendy vzdelávania v mediácii : zborník z medzinárodnej vedeckej konferencie "Mediácia 2017", ktorá sa konala v Modre v dňoch 7. až 8. apríla 2017. - Bratislava : Asociácia mediátorov Slovenska, 2017. - ISBN 978-80-971616-6-8, S. 169-182.

26. VANKOVÁ, K.: Mediation in civil law in the perception of interpersonal relationships and its use in practice with an emphasis on peer-mediation; recenzent: Ján Gabura, Dušan Ondrušek, 2015. In. Obec - škola mediácia : zborník z II. ročníka medzinárodnej vedeckej konferencie konanej v Modre v dňoch 16. - 17. 04. 2015. - Bratislava : Asociácia mediátorov Slovenska, 2015. - ISBN 978-80-971616-2-0, S. 254-268.

27. VANKOVÁ, K.: Methods of experiential education and their application in education outside the classroom. Educatiopress. Bratislava. Vychovávatel'. 2018. 9-10, roč.LXVI. ISSN 0139-6919, EV 176/08.

28. VANKOVA, K.: Differences should unite us, not divide us! Nitra. OZ Sponka. 2014. ISBN 978-80-971863-0-2

29. Act No. 420/2004 Coll. on Mediation and on Amendments to Certain Acts.

30. Act No. 245/2008 Coll. on education and training (Education Act) and on amendments to certain acts. 